\title{
Using GIS and cartography as part of the whole-of-society approach to determine coercion into marine wildlife poaching and piracy
}

\author{
Peter Schmitz ${ }^{\mathrm{a}, \mathrm{b}} *$, Duarte Gonçalves ${ }^{\mathrm{c}}$ \\ ${ }^{a}$ Department of Geography, University of South Africa, Christiaan de Wet Dr, Florida, Roodepoort, South Africa,schimpmu@unisa.ac.za \\ ${ }^{b}$ Fakultät für Vermessung, Informatik und Mathematik, Hochschule für Technik, Stuttgart, Schellingstrasse 24, D-70174, Stuttgart, Germany \\ ${ }^{c}$ CSIR Defence, Peace Safety and Security, Meiring Naude Rd, Brummeria, Pretoria, South Africa, DGoncalv@csir.co.za \\ * Corresponding author
}

\begin{abstract}
This paper builds on a previous paper on determining a community's vulnerability to coercion into wildlife crimes along South African game reserves with a focus on rhinoceros poaching. This paper looks at the profiling of coastal communities along the South African coast for possible coercion into piracy and marine wildlife crime as context for a whole-of-society approach. As with the previous paper the criteria and data are based on publicly available resources to do the profiling. Criteria range from access to motorised boats, history of illegal, unregulated and unreported fishing activities, poverty, unemployment, closeness to marine reserves and levels of education. The criteria for piracy are based on articles and reports on the reasons for piracy along the Somalian coast. From the analysis the highest risk for piracy is the south-western Cape around Cape Town since the proximity to international sea routes, the ability of the local population to do deep-sea fishing and existing gang activity. The risk to marine resources is similar owing to the same reasons as for piracy. It is a known fact that gangs are involved in the poaching of abalone along the south-western Cape coast. Socio-economic risks are higher along the east coast of South Africa owing to higher unemployment, poverty and lower education levels.
\end{abstract}

Keywords: piracy, poaching, marine resources, communities, criteria.

\section{Introduction}

This paper builds on the work by Schmitz et al. (2017) on determining the vulnerability to coercion of communities next to game reserves into poaching of wildlife. This paper investigates the use of spatial data, non-spatial data, Geographic Information Systems (GIS) and cartography to determine the vulnerability to revert or be coerced into marine wildlife crimes and/or piracy of coastal communities. The criteria are based on information available in the public domain such as articles by journalists, academia; reports and data from government institutions, non-profit organisations and regional bodies. Piracy criteria are mostly based on literature by Kerins (n.d.) Jablonski \& Oliver (2012); Steenhard (2012) and Allison (2017) covering piracy along the Somalian coast. These are augmented by literature from Clark et al. (2002), Isaacs, (2006) and Faasen \& Watts (2007) on fishing activities along the South African coast to determine whether some of the issues raised along Somali coast are happening along the South African coast. Based on the study, the possibilities for piracy do exist along the South African coast. However, the present political, judicial and economic climate of South Africa makes piracy at present a low risk. If South Africa turns to the worst in the future, the risk of piracy along the coast, especially the area around Cape Town could be very high with a significant impact on world-wide maritime traffic.

With regards to marine wildlife poaching activities, these are similar to wildlife crimes as discussed in Schmitz et al (2017) except that they also occur outside marine reserves. Abalone, oysters and rock lobsters are highvalue marine resources and the most poached marine resources by criminal syndicates and individuals. The paper is divided as follows: first the whole-of-society concept is discussed in the context of piracy and marine wildlife crimes, followed by a discussion on the criteria and vulnerability of communities. The methodology followed is discussed ending with a discussion of the results and conclusions.

\section{Whole-of-Society Introduction}

The whole-of-society approach indicates the inclusion of society, organisations and government where the society and not only government takes an active role in conservation, disaster resilience or security, to list a few examples (Lindberg \& Sundelius, 2012; Gonçalves, 2017). Currently, worldwide, there is a trend to reconsider the security chain, which consists of four generic tasks, namely analysis, prevention, response and evaluation on responding to incidents (de Spiegeleire, 2011). However, the outcome of a response is never certain and can have profound consequences. Thus, the 
shift moves to prevention and analysis, which includes foresight, and not only responses to incidents.

It is critical to note that the security chain must be applied faster than the problems are changing. The consequence of this is that the ability of organisations to respond to changes in dynamic or uncertain environments requires high levels of integration (Hoogervorst, 2009). When multiple organisations are involved, this integration must extend across organisations. Integration of organisations is dependent on sharing and integration of information, which provides the basis of collaboration. However, this is not a guarantee that organisations will work together to achieve a common goal. Furthermore, even if collaboration is promulgated it may ignore corruption or power issues that may hinder a collaborative effort to respond to and curb criminal activities along the coasts which include the poaching of marine wildlife and piracy. Schmitz et al. (2017) gives an overview of the whole-ofsociety approach with regards to wildlife crimes and possible coercion of communities into wildlife crime in South Africa.

In the context of disaster management, some practitioners and researchers define risk in terms of vulnerability exposed to a hazard (Coppola, 2015). "Coping capacity", which includes resources and capabilities, reduce the extent of the impact. Capability is central to a whole-ofsociety approach as contemplated by some researchers (Gonçalves, 2017). In Figure 1, we extend the determinants of risk, building on the understanding from disaster management. Before proceeding, we note that risk is only one way of framing the issue - it is a framework that will be used in this article. Firstly, threats and hazards are considered and could range from a climate induced crop failure to a cyber-attack on a tanker in a harbour. Resources are a combination of natural resources, social and human resources, financial resources, and manufactured resources. In the context of disaster management, financial resources are one way of increasing resilience, which allows rebuilding after a disaster. The same resources that are essential for value creation or risk mitigation also attract attention from criminals, for example, wildlife such as rhino, attracts tourists and poachers. Skills that are used for legal fishing can easily be used for illegal fishing and with more effort can be adapted for piracy under the right conditions. Capabilities have been expanded here in three categories of capability to: deal with threats and hazards, reduce vulnerability, and protect resources. This emphasises responsive as well as proactive developmental efforts of a whole-of-society approach (Nussbaum, 2011; Collins, 2009).

\section{Identifying vulnerability to involvement in criminal activity}

This article expands on the work done by Schmitz et al. (2017) using various research articles which will be referred to as appropriate. A proper understanding of the context is important to successfully implement a wholeof-society approach to prevent marine wildlife poaching and piracy. Whole-of-society approach is used to understand the "society" as a whole along the South African coastline including the communities using marine resources for their own consumption or for financial gain. This includes the implications of legislation by the South African government as well as the activities of illegal international fishing fleets. The latter is based on Kerins (n.d.) and Allison's (2017) observations on the relationship of depleted fishing stocks by illegal fishing fleets and piracy along the Somali coast.

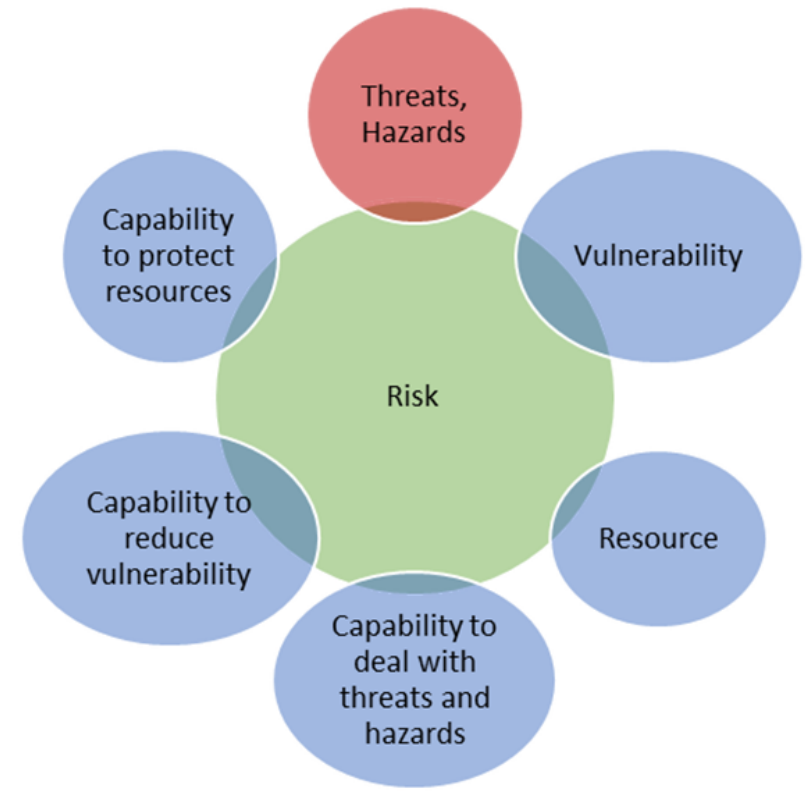

Figure 1. Revisiting risk from a whole-of-society perspective.

\subsection{Drivers that may lead to criminal activity}

Kerins (n.d.), Jablonski \& Oliver (2012) and Steenhard (2012) indicate that the following issues lead to piracy and other crimes along the Somali coast:

- Lack of economic opportunity such as poor access to the labour market and unemployment were identified as the principal drivers of pirate recruitment.

- Illegal fishing by foreign vessels was characterized as the fundamental grievance that sparked piracy and provides ongoing justification for it.

- Illegal dumping of hazardous wastes along the Somali coast further decimated the fishing stock.

- Locals resent the international navies, believing they are in Somali waters specifically to protect illegal foreign fishing.

- Attitudes towards naval forces are much more positive in areas where they have established direct, cooperative relationships with coastal communities. 


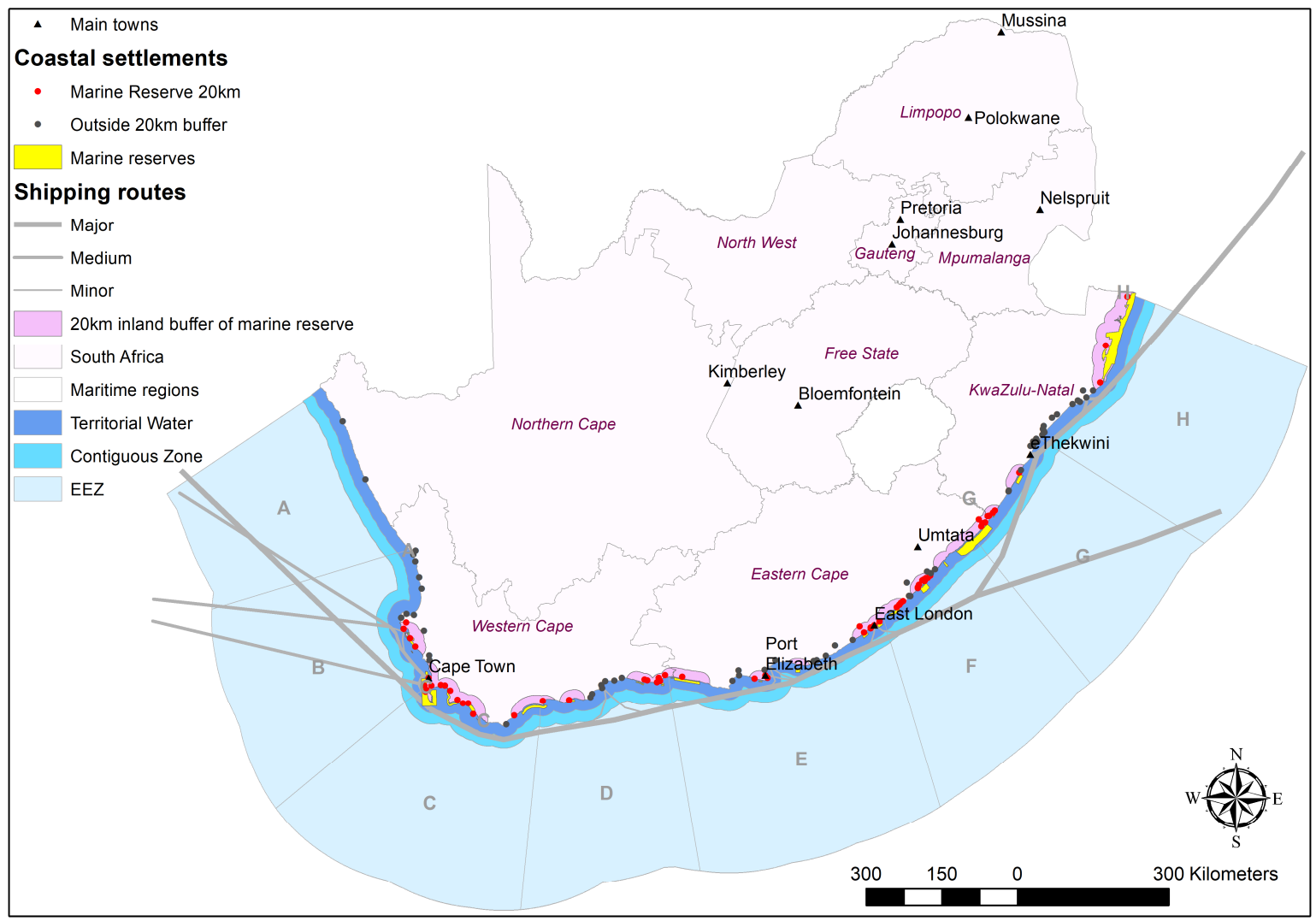

Figure 2. Overview of marine reserves, shipping lanes and coastal fishing communities.

- There is widespread agreement that without changes to the underlying conditions, piracy will return.

\subsection{Fishing communities}

Keeping the aforementioned in mind, several research activities were conducted with regards to fishing activities in South Africa. The focus of most of the research was on small scale fishing, which includes subsistence and artisanal fishing activities, whether legal or illegal and the impact of conservation and legislation on these activities (Clark et al. 2002, Isaacs, 2006, Faasen $\&$ Watts, 2007). Isaacs (2006) looks at the implications of the government's "one-size-fits-all" approach in granting fishing access rights and how it affected the small fishers. In most cases it affected them negatively owing to various reasons ranging from difficulty in completing the application forms to alleged corruption (Isaacs 2006). Faasen \& Watts (2007) looked into the issues of conservation and how it was understood by the local community with regards to fishing and how it was understood by South African National Parks (SANParks). Local communities understood that conservation of marine resources guaranteed future use, but they saw it in conjunction with responsible use of these resources whereas SANParks used a "no-take" policy which led to conflict between these two groups (Faasen \& Watts, 2007).

Clark et al. (2002) conducted research to determine the distribution of small-scale fishers along the South African coast. Figure 1 indicates the location of settlements, both urban and rural, along the coast. Figure 2 also shows the location of marine reserves, a $20 \mathrm{~km}$ buffer around these reserves, the various economic zones along the coast and the shipping routes. The $20 \mathrm{~km}$ buffer areas around the reserves are based on Schmitz et al. (2017), which is a distance that a person can walk in a day or night to a reserve, harbour, launching site or beach. This is also further substantiated by Clark et al. (2002) where authors indicated that small scale fishers in general live up to $15 \mathrm{~km}$ from their fishing areas.

Clark et al (2002) list the following marine resources used by small-scale fishers, namely rocky-intertidal invertebrates such as red algae used in the agar industry, brown mussels, Cape Rock Oyster, sea weed, and mussels; sandy-beach invertebrates such as white mussels, sea snails and some crab species; estuarine invertebrates such as oysters; rock lobster; abalone; sea weed and fish. Oysters, abalone and rock lobsters are high-value goods that are sold for profit. These, especially abalone, are subject to marine wildlife crimes.

\section{Methodology}

The methodology to determine and map the levels of vulnerability to coercion into marine wildlife crimes and/or piracy consists of four phases. The first phase is the identification of the criteria that could make a community vulnerable such as access to deep sea boats, proximity to marine reserves and socio-economic factors; the heuristic weighting of the criteria; data gathering and calculation of the criteria values; and the mapping of the 


\begin{tabular}{|l|l|}
\hline Criterion & Description \\
\hline $\begin{array}{l}\text { Level of detection: } \\
\text { IUU fishing }\end{array}$ & $\begin{array}{l}\text { The country's ability to curb illegal, unreported and unregulated (IUU) fishing activities } \\
\text { which may lead to the depletion of fishing stock. } \\
\text { There are indications of issues with capacity to detect IUU fishing activity - high risk (4). }\end{array}$ \\
\hline $\begin{array}{l}\text { Road kilometre per } \\
\mathrm{km}^{2} \text { per sub-place }\end{array}$ & $\begin{array}{l}\text { The more roads, the easier the access to the marine parks and other marine areas as well as } \\
\text { to ship poached marine resources such as rock lobsters and abalone. } \\
\text { Used natural breaks (Jenks) to determine } 5 \text { classes road km per square km. Lowest density } \\
\text { - very low Risk (1) and highest density very high (5) risk. }\end{array}$ \\
\hline No education & $\begin{array}{l}\text { Measured for heads of households and expressed as a percentage per sub-place. Could } \\
\text { indicate difficulty in finding alternative employment. } \\
\text { Very low risk (1) for the range } 0 \text { to } 20 \text { percent; low risk (2) for } 20 \text { to } 40 \text { percent; medium } \\
\text { risk (3) for } 40 \text { to } 60 \text { percent; high risk (4) for } 60 \text { to } 80 \text { percent; and very high risk (5) for } \\
80 \text { to } 100 \text { percent. }\end{array}$ \\
\hline
\end{tabular}

Table 1. Calculating levels of risks for each criterion.

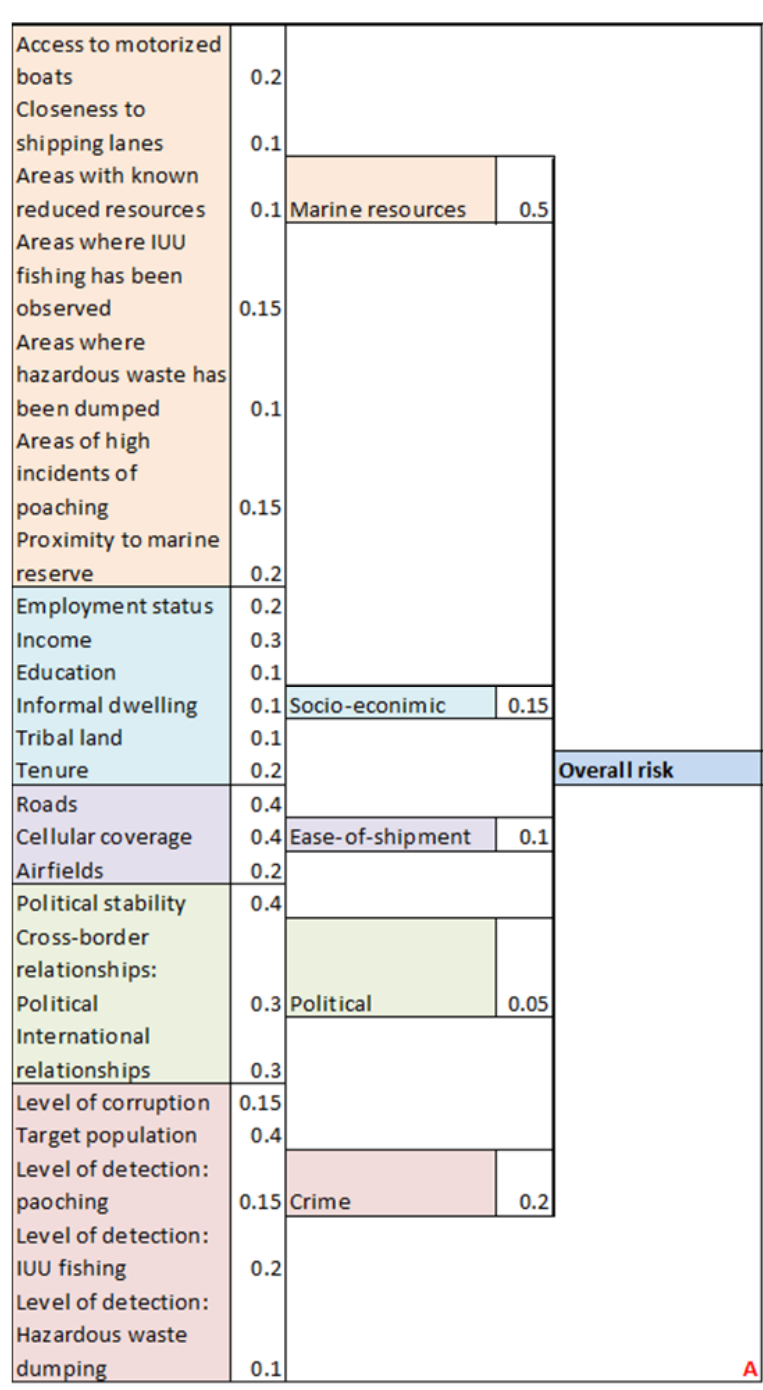

Figure 3. Grouping of risks (a) and identifying risks (b).

results using a GIS (Schmitz et al., 2017 and Schmitz, 2018).

The identification of criteria was determined from various sources in the public domain such as research articles, articles by journalists, reports and other publications. From these the criteria were derived and how the risk levels can be calculated (Schmitz et al., 2017 and Schmitz,

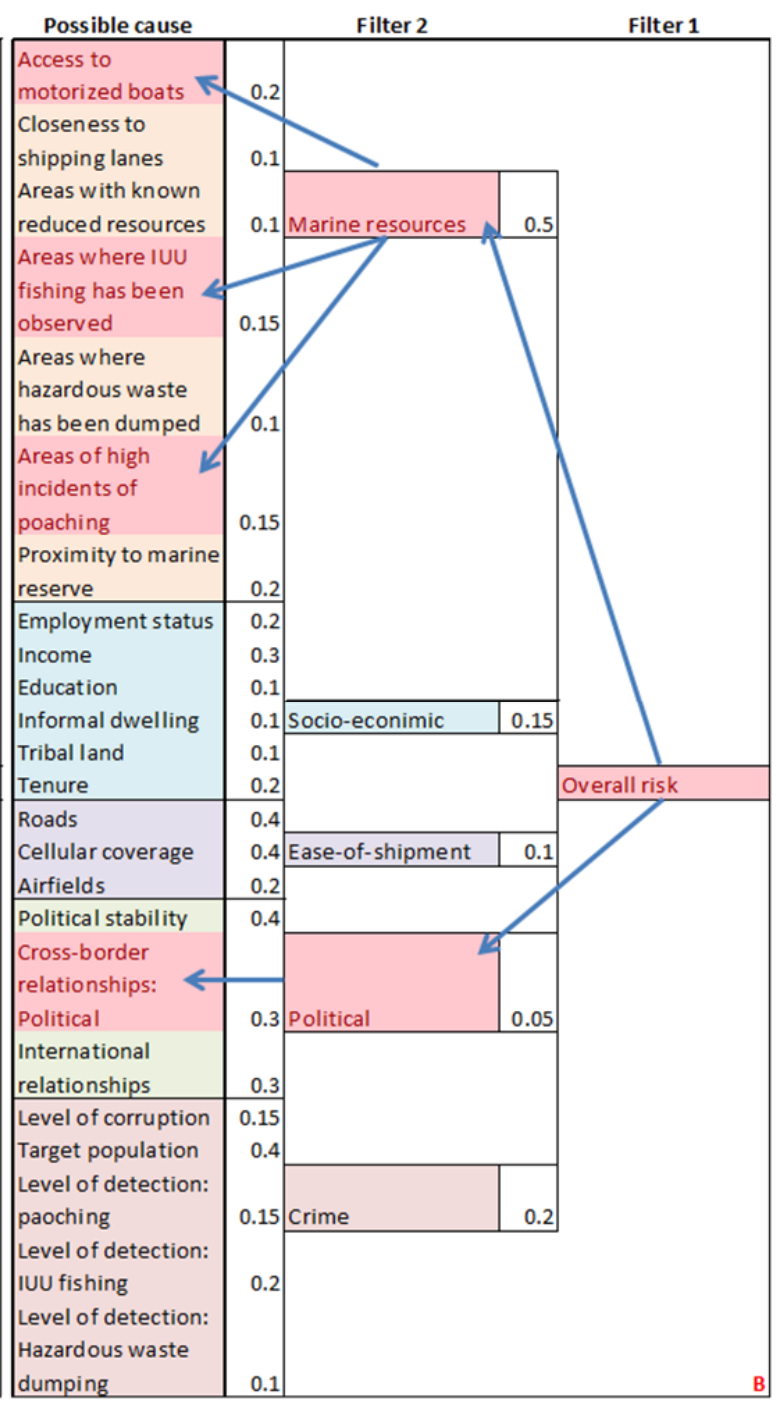

2018). Table 1 gives an example of the identified criteria and associated risk levels.

These identified criteria have been grouped into classes, which are in turn weighted heuristically to give the overall risk to a community as indicated in Figure 3. The second phase was to determine the weights using the heuristic method using the methodology described in Schmitz (2018). The third phase determined which data 


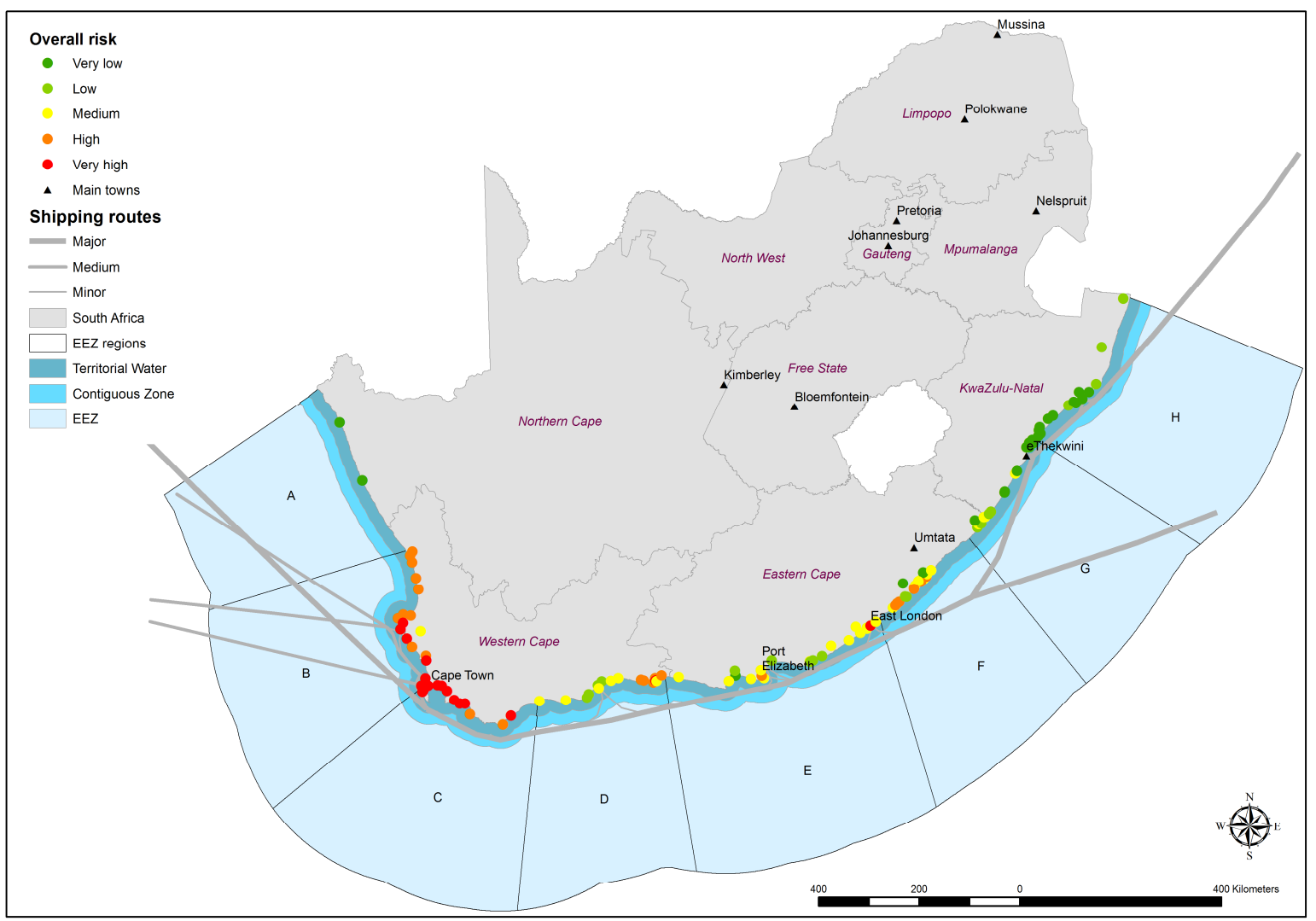

Figure 4. Overall risk for coercion into piracy and marine wildlife crimes.

was required to estimate the risks and to source the data. Socio-economic data was determined from the Census 2011 data from Stats SA; cell phone coverage was based on maps from the various service providers showing their coverage; Clark et al (2002) report was used to determine data on fishing communities; and the Department of Agriculture, Forestry and Fisheries' 2014 status report on marine fishery resources was used to determine the availability of fishing stocks and illegal, unreported and unregulated (IUU) fishing activities (DAFF, 2014).

The final phase was to create various maps to illustrate the various risk levels using a GIS.

\section{Results}

A Geographic Information System (GIS) was used to map the various risk levels as discussed in the aforementioned section. Figure 4 shows the overall risk of communities being coerced into illegal marine activities. Illegal maritime activities in this context ranges from poaching, over-fishing and over-harvesting of marine resources to piracy. The communities with the highest risk to coercion into illegal marine activities are those of regions $\mathrm{B}$ and $\mathrm{C}$. These regions are known for current severe poaching of abalone and are regions with a history of gang problems, especially the communities in and around Cape Town (Steinberg, 2005). Regions A and $\mathrm{H}$ shows the lowest risk. The reason for Region $\mathrm{H}$ having a low risk is that there is a working relationship between the communities and the reserves, especially with the communities around the Kosi Bay iSimangaliso Wetland Park. Communities are allowed to fish in Kosi Bay using
Thonga Fish Kraals that are passed on from one generation to the next and are strictly controlled and are allocated to families to fish in specific areas.

Figure 5 shows the marine resources risk for each of the coastal communities. Regions $\mathrm{B}$ and $\mathrm{C}$ are seen with the highest risk followed by Region $\mathrm{D}$. These regions are vulnerable owing to access to motorized boats as well as the high-level of abalone poaching in Regions $\mathrm{B}$ and $\mathrm{C}$. Further risk is that these regions $(\mathrm{B}, \mathrm{C}$ and $\mathrm{D})$ have major shipping lanes close to the shore, combined with the high access to motorised boats; the communities in these regions could be coerced into piracy if a Somali type of situation develops in South Africa. Fortunately, the political risk is currently medium in South Africa, even with the current political turmoil the junk rating of the South African economy. However, the latter may impact on the socio-economic risks which could cause an increased risk of vulnerable communities along the coast to be coerced into illegal maritime activities.

Figure 6 shows the socio-economic risks to vulnerable communities along the coast. Although Regions B and C are high-risk areas with regards to vulnerable communities it is interesting to note that the socioeconomic risks are lower when compared to Regions E to $\mathrm{H}$. The communities in Regions $\mathrm{E}$ to $\mathrm{H}$ may have higher socio-economic risks but the risks with regards to marine resources are lower. If the socio-economic risks are addressed in these areas it will reduce the risk of these communities being coerced into illegal maritime activities. Whereas the emphasis in Regions B, C and D should be linked to reduce maritime resources risks (see 
Figure 5) such as curbing poaching activities. Access to motorized boats is not a risk, but then access to motorized boats could become a risk in the future since it provides opportunities for involvement in a wide range of illegal maritime activities.

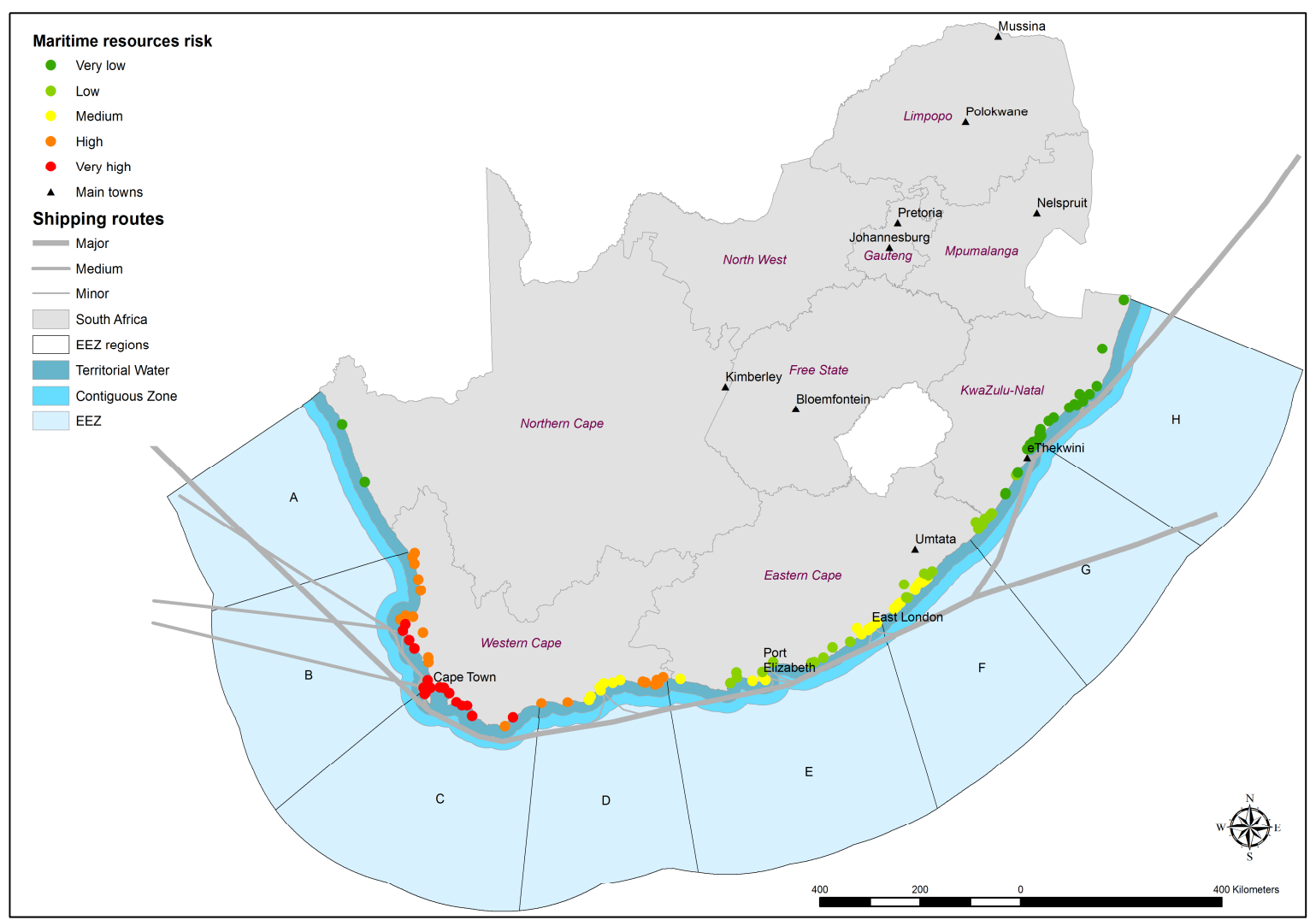

Figure 5. Marine resources risk.

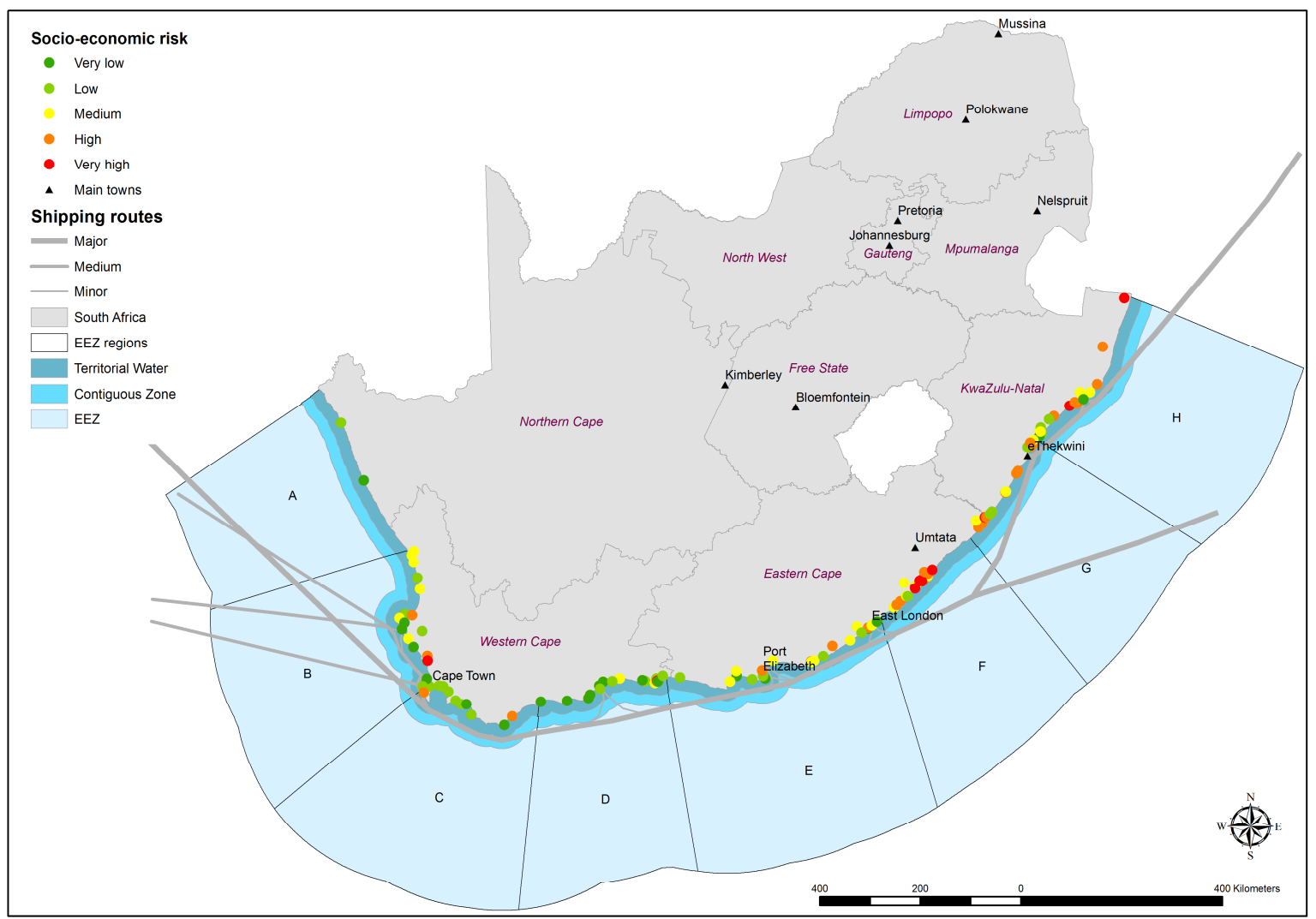

Figure 6. Socio-economic risks.

Advances in Cartography and GIScience of the International Cartographic Association, 1, 2019.

29th International Cartographic Conference (ICC 2019), 15-20 July 2019, Tokyo, Japan. This contribution underwent

single-blind peer review based on the full paper. https://doi.org/10.5194/ica-adv-1-18-2019 | @ Authors 2019. CC BY 4.0 License. 


\section{Conclusions}

This paper is a continuation of the work discussed in Schmitz et al (2017) with an emphasis on coastal communities whereas the emphasis in Schmitz et al

(2017) was on communities surrounding game reserves in South Africa. This paper illustrates the importance of context in a whole-of-society approach when combatting certain crime issues. As with the Somalian example of how Somalis ended up being pirates owing to the depletion of their maritime resources on which their survival depended upon by foreign fishing fleets committing IUU fishing activities. This was further exacerbated by the illegal dumping very hazardous materials such as radioactive waste and chemicals which further decimated their marine resources.

Curbing illegal marine activities along the South African coast requires more than just law enforcement, a wholeof-society approach to is imperative to reduce community vulnerability.

Owing to the current inabilities to effectively patrol IUU fishing activities, South Africa may have to involve regional and/or international partners to protect its marine resources. Fortunately, IUU fishing activities and the dumping of hazardous materials are not rampant, but it does not exclude rampant IUU fishing activities and dumping of hazardous materials along the South African coast in future. Any foreign assistance needs to be in conjunction with the coastal communities to avoid the same situation as in Somalia, where foreign naval ships are seen as the protectors of the fleets that were causing havoc along the Somalian coast.

Although further research and refinement is required to provide a more accurate picture of the vulnerabilities of these communities along the South African coastline, it is hoped that this approach will assist in determining the critical risk elements that need to be addressed to avoid a similar situation as along the Somalian coast.

\section{Acknowledgements}

The authors would like to thank the CSIR and UNISA for their support. Special thanks to the independent reviewer of the paper for the valuable inputs. Thank you to UNISA for funding to attend the conference. Final thank you to the ICC 2019 organising committee that the author can present the paper.

\section{References}

Allison, S. 2017: Somalia: Will decimated fish stocks force desperate fishers into piracy again? Daily Maverick, $\quad 30 \quad$ March 2017. https://www.dailymaverick.co.za/article/2017-03-30somalia-will-decimated-fish-stocks-force-desperatefishers-into-piracy-again/. Website accessed on 31 March 2017.

Clark, B.M., Hauck, M., Harris, J.M., Salo, K. and Russell, E. 2002: Identification of subsistence fishers, fishing areas, resource use and activities along the South African coast. South African Journal of Marine Science 24 pp 425-437.
Collins, A. 2009: Disaster and Development. London: Routledge.

Coppola, D. P. 2015: Introduction to International Disaster Management, Butterworth-Heinemann

DAFF, 2014: Status of the South African marine fishery resources, 2014. Department of Agriculture, Forestry and Fisheries, Cape Town, South Africa. http://www.nda.agric.za/doaDev/sideMenu/fisheries/03 areasofwork/Resources $\% 20$ Research/STATUS\%20OF \%20THE\%20SOUTH\%20AFRICAN\%20MARINE\%2 0FISHERY\%20RESOURCES\%202014\%20WEB.pdf

Faasen, H. and Watts, S. 2007: Local community reaction to the 'no-take' policy on fishing in the Tsitsikamma National Park, South Africa. Ecological Economics 64 pp 36-46.

Gonçalves, D. 2017: “A Whole-of-Society Approach to Wildlife Crime in South Africa", SA Crime Quarterly (60), 9-18.

Isaacs, M. 2006: Small-scale fisheries reform: Expectations, hopes and dreams of "a better life for all'. Marine Policy 30 pp 51-59.

Jablonski, R.S. and Oliver, S. 2012: The Political Economy of Plunder: Economic Opportunity and Modern Piracy. Journal of Conflict Resolution 57(4) pp 682-708

Kerins, P. n.d.: Somali Perspectives on Piracy and Illegal Fishing.

http://oceansbeyondpiracy.org/publications/somaliperspectives-piracy-and-illegal-fishing Website accessed on 31 March 2017.

Neth, H. and Gigerenzer, G. 2015: Heuristics: Tools for an uncertain world. In R. Scott and S. Kosslyn (Eds.), Emerging trends in the social and behavioral sciences: An interdisciplinary, searchable, and linkable resource (pp. 1-18). New York, NY: Wiley Online Library. doi: 10.1002/9781118900772.etrds0394

Nussbaum, M. 2011: Creating Capabilities: The Human Development Approach, Harvard University Press.

Schmitz, P. 2018 Geoprofiling of vulnerable communities. Proceedings of the Biennial Conference of the Society of South African Geographers: 1 - 5 October 2018, University of the Free State, Society of South African Geographers, ISBN: 9780868868523

Schmitz, P., Gonçalves, D. and Jacob, M. 2017: Mapping Community Vulnerability to Poaching: A Whole-ofSociety Approach. In: M. P. Peterson, ed. Advances in Cartography and GIScience: Selections from the International Cartographic Conference 2017. Cham: Springer International Publishing AG.

Steinberg, J. 2005: The illicit abalone trade in South Africa. ISS Paper 105, April 2005. Institute for Security Studies, South Africa. 